\title{
STUDI KELAYAKAN RENCANA PENDIRIAN RUMAH PEMONDOKAN (KOST) KELAS MENENGAH DI TEGALGONDO MALANG
}

\author{
M. Abdimas Haidar Rahbany \\ Department of Management FEB UMM \\ E-mail: Dimas_haidar@ymail.com
}

\begin{abstract}
The purpose of this research is to determine lodging house feasibility in Malang. Feasibility study includes marketing aspects, technical, economic and social, management, legal, environmental, and financial aspects. Analysis tools used are Net Present Value (NPV), Payback Period (PP), Method of Average Rate of Return (ARR), Method Internal Rate of Return (IRR), and Profitability Index (PI). The results show that ARR is $24 \%$ (more than $17 \%$ minimum requirement), $P P$ is 6.2 year (less than 15 year proposed), NPV is 485.041 (more than 0), IRR is $17.013 \%$ (more than 17\% ARR), and PI is 1.0007287 (more than > 1). All the feasiblity requirement are eligible. It means that the lodging house project is feasible.
\end{abstract}

Keywords: Business Feasibility Research, Net Present Value, Internal Rate of Return, Payback Period, Average Rate of Return, Profitability Index.

\section{PENDAHULUAN}

Kota Malang adalah sebuah kota terbesar kedua di Jawa Timur, terletak $90 \mathrm{~km}$ sebelah selatan Kota Surabaya. Sebagai kota pelajar, Malang memiliki beberapa perguruan tinggi ternama, seperti Universitas Brawijaya (UB), Universas Negeri Malang (UM), dan Universitas Muhammadiyah Malang(UMM). Tingginya tingkat pendatang di Kota Malang, baik untuk kepentingan pendidikan maupun pariwisata juga mendorong perkembangan properti didaerah yang terkenal sebagai Kota Apel ini.

Predikat Malang sebagai kota pelajar adalah sebuah kenyataan tak perlu diasingkan lagi. Setiap tahun jumlah pelajar dan mahasiswa semakin bertambah untuk menuntut ilmu di Malang, bahkan banyak pula yang berasal dari luar negeri. Hal ini juga berdampak pada meningkatnya kebutuhan akan tempat tinggal bagi mereka. Sebagian masyarakat melihat hal tersebut sebagai peluang bisnis, salah satunya adalah rumah kost.

Salah satu perguruan tinggi swasta di Malang yang menjadi favorit calon mahasiswa adalah Universitas Muhammadiyah Malang (UMM). Setiap tahun jumlah mahasiswa mengalami peningkatan, ini terbukti dari data yang dikeluarkan oleh Biro Administrasi Akademik UMM jumlah mahasiswa tahun 2014 pada semester ganjil sebesar 29.993.Lebih jelasnya dapat dilihat pada tabel 1.1 dibawah ini. 
Tabel 1. Jumlah Mahasiswa Universitas Muhammadiyah Malang $2009-2014$

\begin{tabular}{cccccc}
\hline $\begin{array}{c}\text { Mhs } \\
\text { Aktif }\end{array}$ & 2010 & 2011 & 2012 & 2013 & 2014 \\
\hline Gnj1 & 22281 & 24268 & 26171 & 28560 & 29993 \\
Gnp & 20060 & 21939 & 23662 & 25789 & - \\
\hline
\end{tabular}

Pertumbuhan jumlah rumah kost di Malang memang tengah berkembang pesat. Mulai dari kelas sederhana, menengah bahkan banyak juga rumah kos yang dilengkapi fasilitas mewah layaknya hotel berbintang. Seperti yang dikutip dari Dinas Pendapatan Daerah (Dispenda) Kota Malang melalui Kepala Bagian (Kabag) Perekonomian Kota Malang, Mochammad Kharis menyebutkan "Salah satu investasi potensial dan menarik perhatian masyarakat saat ini rumah kost. Sehingga pertumbuhannya termasuk tinggi, bahkan tidak sedikit rumah kost yang memiliki fasilitas mewah layaknya hotel," sebutnya.

Kriteria kost kelas menengah masih menurut Dinas Pendapatan Daerah (Dispenda) Kota Malang yaitu rumah kost mewah atau premium tersebut menurutnya memiliki perlengkapan seperti air conditioner (AC), kamar mandi dalam, air hangat dan tempat parkir untuk kendaraan roda empat. Hasil pengamatan yang telah dilakukan peneliti pada rumah kost kelas menengah didaerah Bukit Cemara Tujuh (BCT) memiliki 9 kamar dengan tarif Rp.500 ribu per bulan untuk setiap kamarnya, dengan fasilitas antara lain kasur, lemari besar, meja, kamar mandi dalam, dapur, tempat jemur, tempat parkir untuk motor dan mobil, serta pembantu untuk bersih-bersih dan mencuci.
Seiring bertumbuh pesatnya kost kelas menengah dan terbukanya peluang bisnis untuk rencana usaha tersebut, maka studi kelayakan bisnis diperlukan untuk dapat dijadikan suatu bahan pertimbangan dalam rencana pendirian usaha yang nantinya layak atau tidak layak usaha tersebut dijalankan.Dalam melakukan studi kelayakan bisnis pertimbangan untuk menggunakan tenaga ahli sesuai dengan profesi merupakan suatu hal yang sangat penting kalau ingin mendapatkan hasil studi yang dapat dipercaya sebagai suatu referensi atau acuan dalam membuat keputusan investasi (Sofyan, 2004:4) Tujuan melakukan studi kelayakan bisnis adalah untuk mengetahui apakah suatu proyek akan mendatangkan keuntungan atau kerugian. Dengan kata lain, untuk memperkecil tingkat risiko kerugian dan memastikan bahwa investasi yang akandilakukan memang menguntungkan. Disinilah fungsi studi kelayakan bisnis merupakan sebuah bentuk rekomendasi yang diberikan kepada pihak pemakai bahwa bisnis tersebut layak atau tidak untuk dijalankan (Syahiruddin dan Hadi, 2009:2).

Lokasi rencana usaha pendirian rumah kost kelas menengah ini bertempat di tanah milik Bapak Waluyo Sugiman, terletak di Dusun Gondang Desa Tegalgondo Kecamatan Karangploso Malang. Alasan memilih lokasi tersebut karena setiap tahunnya jumlah mahasiswa yang melanjutkan studi dikampus Universitas Muhammadiyah Malang terus meningkat, dan peneliti melihat hal tersebut sebagai peluang bisnis untuk kebutuhan akan rumah kost. 


\section{TINJAUAN PUSTAKA}

Berdasarkan penelitian terdahulu yang dilakukan oleh Hellen Mayora Violetha (2014) Mahasiswi Fakultas Ekonomi dan Bisnis Universitas Muhammadiyah Malang melakukan penelitian dengan judul "Evaluasi Kelayakan Bisnis Pada Rumah Pemondokan (Kost) Mahasiswa Di Sekitar Universitas Muhammadiyah Malang”. Penelitian ini menggunakan metode penilaian investasi yaitu PP (Payback Period), ARR (Average Rate of Return), NPV (Net Present Value), IRR (Internal Rate of Return), PI (Profitability Index).

Berdasarkan hasil penelitian dapat disimpulkan bahwa usaha rumah pemondokan (kost) milik Bapak Rofiq dinyatakan layak, karena hasil analisis Net Present Value (NPV) positif atau > 0, Payback Period (PP) diperoleh < umur ekonomis, Internal Rate of Return (IRR) > COC, Average Rate of Return (ARR) > tingkat keuntungan yang diharapkan, Profitability Index (PI) > 1.

Berdasarkan hasil penelitian dapat disimpulkan bahwa usaha rumah pemondokan (kost) milik Ibu Atnah dinyatakan layak, karena hasil analisis Net Present Value (NPV) positif atau >0, Payback Period (PP) diperoleh < umur ekonomis, Internal Rate of Return (IRR) > COC, Average Rate of Return (ARR) > tingkat keuntungan yang diharapkan, Profitability Index (PI) $>1$.

Berdasarkan hasil penelitian dapat disimpulkan bahwa usaha rumah pemondokan (kost) milik Bapak Sofi dinyatakan tidak layak, karena hasil analisis Net Present Value (NPV) negatif atau $<0$,
Payback Period (PP) diperoleh > umur ekonomis, Internal Rate of Return (IRR) < COC, Average Rate of Return (ARR) < tingkat keuntungan yang diharapkan, Profitability Index $(\mathrm{PI})<1$.

Investasi mempunyai pengertian yang sangat luas, terutama bila dikaitkan dengan kegiatan pasar modal sekarang. Setiap kegiatan yang hendak menanamkan uang dengan termasuk investasi, tetapidalam kebiasaan umum, pembicaraan investasi dikaitkan dengan sistem produksi atau dengan kata lain peningkatan aset. Membahas tentang investasi berarti membahas tentang pemanfaatan sejumlah aset yang dimiliki untuk pencapaian suatu tujuan di masa yang datang. Berikut ini dijelaskan mengenai beberapa pendapat ahli mengenai investasi.

Haming dan Basalamah (2003:3) menyatakan bahwa investasi secara umum diartikan sebagai keputusan mengeluarkan dana pada saat sekarang untuk membeli aktiva riil (tanah, rumah, mobil, dan sebagainya) atau aktiva keuangan (saham, obligasi, reksadana, wesel, dan sebagainya) dengan tujuan untuk mendapatkan penghasilan yang lebih besar dimasa yang akan datang.

$\begin{array}{rrr}\text { Studi Kelayakan Bisnis } & \text { Kalah suatu kegiatan yang }\end{array}$ mempelajari secara mendalam tentang usaha atau bisnis yang akan dilaksanakan dalam rangka menentukan layak atau tidaknya usaha tersebut dijalankan (Kasmir dan Jakfar, 2003:7). Objek yang diteliti tidak hanya pada bisnis skala besar saja, tetapi juga pada bisnis atau usaha yang kecil dan sederhana.

Herlianto dan Pujiastuti (2009:2) menyatakan Studi 
Kelayakan Bisnis adalah suatu penelitian terhadap rencana bisnis yang tidak hanya menganalisis layak atau tidak la yaknya bisnis dibangun, tetapi juga pada saat dioperasionalkan secara rutin dalam rangka pencapaian keuntungan yang maksimal untuk waktu yang tidak ditentukan.

Aspek pasar dan pemasaran merupakan dua sisi yang tidak dapat dipisahkan satu sama lainnya. Pasar dan pemasaran memiliki tingkat ketergantungan yang tinggi dan saling memengaruhi satu sama lainnya. Dengan kata lain, setiap ada kegiatan pasar selalu diikuti oleh pemasaran dan setiap kegiatan pemasaran adalah untuk mencari atau menciptakan pasar (Kasmir dan Jakfar, 2003:43).

Aspek teknis atau operasional dan teknologi artinya, apakah dari segi pembangunan proyek dan segi implementasi operasional bisnis secara teknis dapat dilaksanakan, demikian juga dengan aspek teknologi yang digunakan. Penilaian terhadap aspek ini penting dilaksanakan sebelum bisnis dijalankan, karena akan sangat terkait dengan teknik/ operasional.

Kasmir dan Jakfar (2003:168) menyatakan aspek manajemen merupakan aspek yang cukup penting dianalisis untk kelayakan suatu usaha. Karena walaupun suatu usaha telah dinyatakan layak untuk dilaksanakan tanpa didukung dengan manajemen yang baik, bukan tidak mungkin akan mengalami kegagalan.

Aspek Ekonomi dan Sosial bagi masyarakat adanya investasi untuk meningkatkan pendapatannya. Adapun bagi pemerintah dampak positif yang diperoleh adalah dari aspek ekonomi memberikan pemasukan berupa pendapatan baik bagi pemerintah pusat maupun daerah.

Aspek hukum dalam menilai studi kelayakan bisnis, dokumen yang perlu diteliti keabsahan, kesempurnaan dan keasliannya meliputi badan hukum, izin-izin yang dimiliki, sertifikat tanah atau dokumen lainnya yang mendukung kegiatan usaha tersebut. Kegagalan dalam penelitian aspek ini akan berakibat tidak sempurnanya hasil penelitian, dengan kata lain apabila ada dokumen yang tidak sempurna pasti akan menimbulkan masalah dikemudian hari.

$\begin{array}{ccr}\text { Seperti } & \text { sudah } & \text { dijelaskan } \\ \text { sebelumnya } & \text { bahwa } & \text { untuk }\end{array}$
menentukan layak tidaknya suatu investasi ditinjaudari aspek keuangan perlu dilakukan dapat diukur dengan beberapa kriteria. Setiap penilaian layak diberikan nilai yang standart untuk usaha yang sejenis dengan cara membandingkan dengan rata-rata industri atau target yang telah ditentukan Kasmir dan Jakfar (2003:99) menyatakan adapun kriteria yang biasa digunakan untuk menentukan kelayakan suatu usaha atau investasi.

Metode Payback Period (PP) merupakan teknik penilaian terhadap jangka waktu (periode) pengembalian investasi suatu usaha dengan cara mengukur seberapa cepat suatu investasi kembali. Dasar yang dipergunakan dalam perhitungan adalah aliran kas bersih (proceed) yang diperoleh setiap tahun bukan laba setelah pajak.Nilai kas bersih merupakan penjumlahan laba setelah pajak ditambah dengan penyusutan (dengan catatan jika investasi $100 \%$ menggunakan modal sendiri). 
Metode Average Rate of Return (ARR) merupakan cara untuk mengukur rata-rata pengembalian bunga dengan cara membandingkan antara rata-rata laba sebelum pajak (EAT) dengan rata-rata investasi.

Net Present Value (NPV) atau nilai bersih sekarang merupakan perbandingan antara PV kas bersih (PV of Proceed) dan PV investasi (capital outlays) selama umur investasi. Selisih antara nilai kedua PV tersebutlah yang kita kenal dengan net present value (NPV).

Internal Rate of Return (IRR) merupakan alat untuk mengukur tingkat pengembalian hasil intern. Ada dua cara yang digunakan untuk mencari IRR.

Profitability Index (PI) atau benefit and cost ratio (B/C Ratio) merupakan rasio aktivitas dari jumlah nilai sekarang penerimaan bersih dengan nilai sekarang pengeluaran investasi selama umur investasi.

Analisis sensivitas merupakan analisis yang dilakukan untuk mengetahui akibat dari perubahan parameter-parameter produksi terhadap perubahan kinerja system produksi dalam menghasilkan keuntungan. Dengan melakukan analisis sentivitas maka akibat yang mungkin terjadi dari perubahanperubahan tersebut dapat diketahui dan diantisifikasi sebelumnya.

Analisis Dampak Lingkungan Hidup (AMDAL)Sebelum suatu usaha atau proyek dijalankan maka sebaiknya dilakukan terlebih dahulu studi tentang dampak lingkungan yang bakal timbul, baik dampak sekarang maupun mendatang.Studi ini disamping untuk mengetahui dampak yang bakal timbul, juga mencarikan jalan keluar untuk mengatasi dampak tersebut. (Kasmir dan Jakfar, 2003:212).

\section{METODE PENELITIAN \\ Lokasi Penelitian}

Lokasi penelitian

dilaksanakan di Jalan Noto Joyo RT.1

RW.01 Dusun Gondang Desa

Tegalgondo Kecamatan Karangploso

Malang. Jenis penelitian yang digunakan adalah jenis penelitian studi kasus. Umar (2001) Studi kasus merupakan penelitian yang rinci mengenai suatu objek tertentu selama kurun waktu tertentu dengan cukup mendalam dan menyeluruh termasuk lingkungan dan kondisimasa lalunya. Definisi operasional dibutuhkan dalam menentukan pemakaian alat yang digunakan untuk mengambil data penelitian sehingga data yang diperoleh sesuai dengan tujuan penelitian. Meliputi Aspek Pasar Pemasaran, Aspek Teknis, Aspek Ekonomi dan Sosial, Aspek Manajemen, Aspek Hukum, Aspek AMDAL, Aspek Keuangan (Payback Period, Average Rate of Return, Net Present Value, Internal Rate of Return, Profitability Index). Jenis data yang digunakan oleh peneliti adalah data kuantitatif berupa rencana penjualan, biaya investasi dan biaya modal kerja. Dan sumber data menurut Sanusi (2011:104) Data Primer dan Data Sekunder.

Teknik analisis data yang digunakan dalam penelitian ini yaitu aspek pasar pemasaran, aspek teknis, aspek ekonomi dan sosial, aspek manajemen, aspek hukum, aspek Amdal, dan aspek keuangan meliputi: Net PresentValue

Net Present Value (NPV) atau nilai bersih sekarang merupakan perbandingan antara PV kas bersih 
(PV of Proceed) dan PV investasi (capital outlays) selama umur investasi.

NPV = Total PV Aliran Kas Bersih - Total PV Investasi

Internal Rate of Return (IRR) merupakan alat untuk mengukur tingkat pengembalian hasil intern.

$$
\mathrm{IRR}=\mathrm{i}_{1}+\frac{\mathrm{NPV}^{1}}{\begin{array}{c}
\mathrm{NPV}^{1}-\mathrm{NPV}^{2} \\
\left.-i^{1}\right)
\end{array}}
$$

Profitability Index (PI) atau benefit and cost ratio (B/C Ratio) merupakan rasio aktivitas dari jumlah nilai sekarang penerimaan bersih dengan nilai sekarang pengeluaran investasi selama umur investasi.

$$
\mathrm{PI}=\frac{\sum P V \text { Kas Bersih }}{\sum P V \text { Investasi }} \times 100 \%
$$

ARR merupakan metode
untuk mengukur rata-rata
pengembalian bunga dengan cara
membandingkan antara rata-rata laba
setelah pajak (EAT) dengan rata-rata
investasi.

$$
\begin{gathered}
\mathrm{ARR}=\frac{\text { Rata }- \text { rata EAT }(\text { average earning after tax })}{\text { Rata }- \text { rata Investasi }(\text { average investment })} \\
\text { Rata }- \text { rata EAT }=\frac{\text { Total EAT }}{\text { Umur Ekonomis }(n)} \\
\text { Payback }- \text { rata Investasi }=\frac{\text { Investasi }}{\text { umur ekonomis }}
\end{gathered}
$$

merupakan teknik penilaian terhadap jangka waktu (periode) pengembalian investasi suatu proyek atau usaha.

$$
P P=\frac{\text { Nilai investasi }}{\text { kas masuk bersih }} \times 1 \text { tahun }
$$

\section{HASIL PENELITIAN DAN PEMBAHASAN}

Pada aspek pasar, hal yang perlu dilakukan untuk di analisis dalam rangka memenuhi studi kelayakan pada rencana pendirian rumah pemondokan (kost) kelas menengah ini adalah menentukan segmen pasar, maka terlebih dahulu melihat segmentasi pasar yang akan dituju yaitu pasar mahasiswa Universitas Muhammadiyah Malang.

Strategi pemasaran yang dilakukan dalam memasarkan rumah pemondokan (kost) adalah dengan cara menawarkan secara langsung didaerah sekitar, menyebarkan brosur serta menyebarkan informasi dari mulut ke mulut atau dikenal dengan istilah word of mouth.

Berdasarkan aspek teknis Fasilitas rumah pemondokan (kost) antara lain memiliki sepuluh kamar masing-masing diisi oleh satu orang penghuni dengan fasilitas kamar mandi dalam, kasur (springbed), almari pakaian, meja+kursi belajar, dan wifi. Fasilitas umum seperti dapur dan perlengkapannya, tempat menjemur pakaian dan parkir untuk motor maupun mobil.

Penentuan lokasi rumah kost berdasarkan pada semakin meningkatnya jumlah mahasiswa yang kuliah di Universitas Muhammadiyah Malang dari tahun ke tahun. Lokasi rumah pemondokan (kost) yang strategis karena berada di kawasan pemukiman masyarakat. Ditambah memadainya fasilitas penunjang seperti terjangkaunya akses listrik, air, jalan, warung makan, jasa laundry, fotocopy, maupun warnet, menjadi alasan dalam penentuan lokasi. Dalam proses pembangunan suatu usaha 
diperlukan sebuah rancangan bentuk bangunan serta ukuran bangunan yang jelas, sehingga dapat berjalan sesuai rencana. Seperti pada gambar 1 dimana luas tanah sekitar $350 \mathrm{~m}^{2}$ dan bangunan yang digunakan seluas 330 $\mathrm{m}^{2}$, terdapat sepuluh kamar dengan ukuran masing-masing $3 \times 5 \mathrm{~m}^{2}$, dapur dan tempat menjemur $3 \times 5 \mathrm{~m}^{2}$, dan sisa lorong $150 \mathrm{~m}^{2}$.

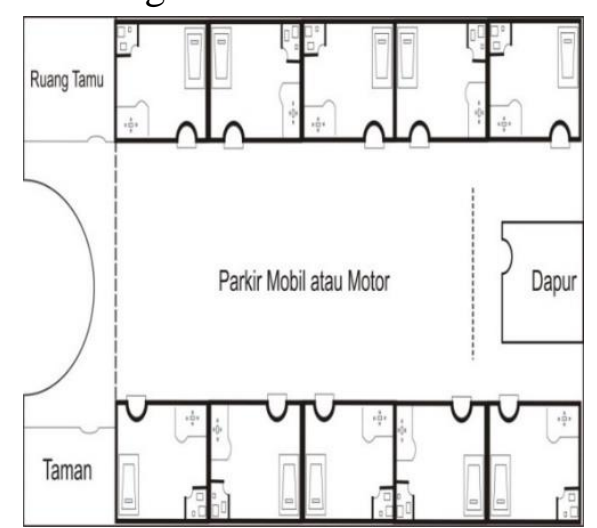

Gambar 1 Bentuk Desain Rumah Pemondokan (Kost)
Berdasarkan aspek ekonomi sosial bagi masyarakat adanya investasi ditinjau dari aspek ekonomi adalah akan memberikan peluang untuk meningkatkan pendapatannya (Kasmir dan Jakfar, 2003:200). Banyak hal positif yang ditimbulkan dengan didirikannya usaha rumah pemondokan (kost) ini antara lainpeningkatan ekonomi bagi pemilik usaha, kesempatan kerja bagi masyarakat sekitar, muncul peluang usaha baru yang sejenis maupun tidak sejenis, pengaruh positif seperti adanya perbaikan jalan, lampu penerang dll.

Berdasarkan aspek manajemen pengelolaan rumah pemondokan (kost) ini tidak menggunakan struktur organisasi. Pengelolaan keuangan dan manajemen usaha rumah kost ditangani langsung oleh pemilik, dan

Tabel 4.15 Interpretasi Hasil Investasi Rumah Pemondokan(Kost)

\begin{tabular}{|c|c|c|c|c|}
\hline No & Penilaian & $\begin{array}{c}\text { Hasil } \\
\text { analisis }\end{array}$ & Kriteria & Kesimpulan \\
\hline \multirow[t]{2}{*}{1} & Payback Period (PP) & $\begin{array}{l}6 \text { Tahun } 2 \\
\text { Bulan }\end{array}$ & & Layak \\
\hline & & & $\begin{array}{l}\mathrm{PP}<\text { usulan } \\
\text { investasi } 15 \\
\text { tahun }\end{array}$ & \\
\hline 2 & $\begin{array}{c}\text { Average Rate of } \\
\text { Return (ARR) }\end{array}$ & $24 \%$ & $\begin{array}{c}\text { ARR > return } \\
(\text { tahun } \\
\text { keuntungan) } \\
\text { yang di } \\
\text { isyaratkan } \\
17 \%\end{array}$ & Layak \\
\hline 3 & $\begin{array}{l}\text { Net Present Value } \\
\text { (NPV) }\end{array}$ & 485.041 & $\begin{array}{c}\mathrm{NPV}>0 \text { atau } \\
\text { bernilai } \\
\text { positif }\end{array}$ & Layak \\
\hline 4 & $\begin{array}{l}\text { Internal Rate of Return } \\
\text { (IRR) }\end{array}$ & $17.013 \%$ & $\begin{array}{c}\text { IRR > dari } \\
\text { suku bunga } \\
\text { yang telah } \\
\text { ditetapkan } \\
17 \%\end{array}$ & Layak \\
\hline 5 & Profitability Index (PI) & $\begin{array}{c}1.0007287 \\
\text { kali }\end{array}$ & $\mathrm{PI}>1$ & Layak \\
\hline
\end{tabular}


pemilik mengendalikan langsung dan berwenang dalam pengambilan keputusan usahanya.

Pemilik memiliki satu tenaga kerja yaitu bertugas sebagai seorang pembantu atau tukang bersih-bersih. Jam kerja pembantu dimulai pada pagi hari pukul 07.00 sampai siang pukul 13.00. Gaji intensif yang diberikan sebesar Rp.800.000/bulan beserta tunjangan hari raya.

Aspek hukum yang dimaksud dalam penelitian ini antara lain jenis badan usaha perseorangan yaitu hanya dimiliki oleh seorang diri, status atau sertifikat kepemilikan tanah yang adalah hak milik pribadi, serta izin mendirikan bangunan (IMB) kategori tempat usaha dengan biaya perijinan Rp.3.000.000. Perijinan dapat dilakukan melalui izin RT/RW setempat sampai pada pemeriksaan akhir pada Badan Pelayanan Perizinan Terpadu (BP2T). Serta pajak rumah kost yang dikenakan oleh Dispenda Malang sebesar 5\% dari penghasilannya apabila jumlah kamar kos 10 ataupun lebih.

$\begin{array}{rrr}\text { Studi menegenai } & \text { AMDAL } \\ \text { merupakan } & \begin{array}{r}\text { salahsatu } \\ \text { syara }\end{array}\end{array}$ kelayakan usaha sebelum melakukan suatu kegiatan proyek. Tidak ada dampak negatif yang ditimbulkan dalam membangun usaha pemondokan rumah (kost) ini, karena untuk pembuangan limbah atau pembuanagan akhir septitang menggunakan tangki/SPAL yang telah dikelola pemerintah, untuk limbah sampah terdapat tempat pembuangan sampah (TPS) khusus yang dikelola oleh daerah setempat, jadi tidak sembarangan dalam membuang sampah.
Berdasarkan hasil analisis data pada kriteria penilaian investasi di atas, maka interpretasi hasil analisis rencana pendirian rumah pemondokan (kost) kelas menengah di Tegalgondo Malang dapat dilihat pada tabel 4.15.

Hasil penelitian menunjukkan bahwa rencana pendirian rumah pemondokan (kost) kelas menengah di Jalan Noyo Joyo RT. RW.01 Tegalgondo Malang layak untuk di jalankan mengingat hasil analisis memenuhi kriteria dari masingmasing penilaian investasi. Nilai ARR (Average Rate of Return) sebesar 24\%, nilai PP (Payback Period) adalah 6 Tahun 2 Bulan, nilai NPV (Net Present Value) sebesar 485.041, nilai IRR adalah $17.013 \%$, sedangkan nilai PI (Profitability Index) sebesar 1.0007287 kali.

\section{SIMPULAN}

Hasil analisis perencanaan pendirian rumah pemondokan (kost) kelas menengah di Dusun Gondang Desa Tegalgondo Kecamatan Karangploso Malang yang telah diuraikan pada BAB IV, menyatakan layak untuk dilakukan berdasarakan penilaian aspek-aspek studi kelayakan bisnis antara lain aspek pasar pemasaran, aspek teknis, aspek ekonomi sosial, aspek manajemen, aspek hukum, aspek AMDAL, dan aspek keuangan.

\section{DAFTAR PUSTAKA}

Haming, Murdifin, dan Basalamah, Salim. 2003. Studi Kelayakan Investasi: Proyek dan Bisnis. Cetakan Pertama. Jakarta: PPM.

Herlianto, Didit, dan Pujiastuti, 
Triani. 2009. Studi Kelayakan Bisnis. Edisi Pertama. Yogyakarta: Graha Ilmu.

Husein, Umar. 2001. Studi Kelayakan Bisnis. Edisi 2. Jakarta: PT. Gramedia Pustaka Utama.

Jakfar dan Kasmir. 2003. Studi Kelayakan Bisnis. Edisi Revisi. Jakarta: Kencana.

Sanusi, Anwar. 2011. Metodologi Penelitian Bisnis. Jakarta Selatan: Salemba Empat.

Sofyan, Iban. 2004. Studi Kelayakan Bisnis. Edisi Pertama. Yogyakarta: Graha Ilmu.

Subagyo, Ahmad. 2007. Studi Kelayakan: Teori dan Aplikasi. Jakarta: PT Elex Media Komputindo.
Sucipto, Agus. 2010. Studi Kelayakan Bisnis: Analisis Integratif dan Studi Kasus. Cetakan Pertama. Malang: UIN-Maliki Press.

Syahiruddin, Irham Fahmi, dan Hadi, Yovi Lavianti. 2009. Studi Kelayakan Bisnis: Teori dan Aplikasi. Bandung: Alfabeta.

Violetha, Hellen Mayora. 2014. Evaluasi Kelayakan Bisnis Pada Rumah Pemondokan (Kost) Mahasiswa Di Sekitar Universitas Muhammadiyah Malang.UMM: Malang

Malang Post. Minggu, 15 Desember 2013

http://www.bi.go.id/id/moneter/lelan g-sbi, 11 Oktober 2014 